\title{
Recent changes in the Hungarian healthcare system, 2010-2017
}

\author{
Péter Mihályi
}

Department of Macroeconomics, Corvinus University of Budapest, Hungary

Address for correspondence: Péter Mihályi, Chair, Department of Macroeconomics, Corvinus University of Budapest, Hungary, tel. 36309748 449, peter@mihalyi.com

\section{Abstract}

The paper provides a narrative and an assessment of the most important changes in the Hungarian healthcare during the $2^{\text {nd }}$ and $3^{\text {rd }}$ Orbán governments. The most important aspect is to understand that during this period the healthcare sector was not a priority, but nevertheless fundamental changes occurred. The explanation is that the Prime Minister, Viktor Orbán, completely restructured the entire constitutional arrangements and the changes affected the healthcare sector. The two main strategies were renationalisation and centralisation. The relative independence of the healthcare sector, which was the result of the reforms occurring between 1992 and 2010, was almost fully reversed and the Ministry of Health ceased to exist in 2010 .

Key words: healthcare, Hungary, health insurance, reforms, social security system, renationalization

Stowa kluczowe: opieka zdrowotna, reformy, renacjonalizacja, system zahezpieczenia społeczneyo, ubezpieczenie zulowotne, Weg̣ry

\section{Introduction}

Seven years is not a long time in the history of a modern country's healthcare system. In peace time, a large and complex network of institutions with millions of stakeholders does not usually undergo rapid changes. This should be even more so in a political environment, as in the case of Hungary, where the incumbent government was not even aiming at a profound restructuring of the healthcare sector. Interestingly, however, the Hungarian healthcare system did change in many important ways as a consequence of fundamental changes in other parts of Hungarian society. As the Speaker of the Hungarian National Assembly recently articulated, "during the last seven years the entire house has been transformed from the basement to the roof". This really is what has happened to the country. The main objective of this paper is to show foreign readers the sequence of changes that occurred in the country's constitutional and political settings and how they affected the healthcare system. This can be particularly relevant for Polish readers, given the well-known similarities of the current political leadership in Hungary and that in Poland.

\section{A reversal of the post-communist economic reforms}

The general election in April 2010 resulted in a $2 / 3$ majority for Viktor Orbán, the leader of the centre-right party, FIDESZ. ${ }^{1}$ To date, he has been Prime Minister for seven years. Although, it may look strange for anyone outside Hungary, it was not a political party that won the election, but a single person. However, this is the fundamental fact that is needed to understand the current situation in Hungary. All the power is in his hands. When the party was founded in 1988, as a youthful, libertarian, anti-communist movement, it chose the name FIDESZ an acronym of the Hungarian Words Alliance of Young Democrats. Victor Orbán, at the age of 25, the holder of a law degree, was already the de facto leader of the party, but his power was somewhat limited by his young friends. However, over a period of 4-5 years, he entirely suppressed any rivalry and all dissent within the party. By 1995, the party had moved from the liberal left to the conservative right; the party of young Budapest intellectuals had been transformed into the party for the voters of middle-size towns and villages. ${ }^{2}$ In the scope of international politics, FIDESZ initially joined Liberal Inter- 
national in 1992, but later switched its allegiance and left the organisation in 2000. When Hungary was admitted to the EU in 2004, FIDESZ joined the European Peoples' Party group sitting in the European Parliament. With the unprecedented centralisation of power, surpassing anything that the country had experienced in the entire $20^{\text {th }}$ century, Orbán won three parliamentary elections, in 1998, 2010 and 2014, and now has a good chance to win again in 2018.

To the great surprise of the outside world, the outcome of the 2010 elections $^{3}$ was the complete reversal of the process of political and economic reform. Many Hungarians were also surprised. After Orbán's landslide victories, politics captured the commanding heights of the economy; market rationality has been relegated to a secondary position. The most prominent Hungarian economist, János Kornai [1] was right in calling this a dramatic U-turn. Within a few months, a new constitution [2] and many new laws were approved in the uni-cameral National Assembly with the explicit aim of removing all the classical checks and balances present in representative democracies. As Orbán himself famously stated, his aim was to convert Hungary from a liberal to an illiberal democracy. ${ }^{4}$ Most of the new laws were directed towards achieving greater administrative centralisation and creating an unlimited manoeuvring space for the state authorities - including the right to conceal publicly relevant information. The concepts of a socialist market economy, private ownership and social insurance were all removed from the constitution without any public explanation or discussion. Virtually all acts, affecting the limits of state power and ownership were converted to "cardinal" laws, requiring a $2 / 3$ majority for any changes. It was mostly symbolic, but nonetheless noteworthy, that the word Republic was also discarded from the full, official name of Hungary. The Ministry of Health was abolished, and all its earlier competencies were taken over by a super-ministry, called the Ministry of Human Capacities. The new Ministry has an exceptionally wide portfolio of responsibilities, specifically family, youth, churches, national minorities, civil society, culture, education, sport, social affairs and health.

From the healthcare viewpoint, two formal constitutional changes were of utmost importance. Firstly, the legal basis of social insurance was removed from the text. This meant - inter alia - that earlier constitutional regulations guaranteeing free and equal access to health care were discarded. Since the new constitution does not specify the ways and means of financing healthcare, the default interpretation is that it is the function of the state and the state's budget. Although it did not lead to changes in the resources, it is worth noticing that since 2012 the unified social insurance contribution (27\%) paid by employers - which consists of pension, health insurance and labour market contributions - has been officially renamed as the social contribution tax. ${ }^{5}$ However, paying this tax does not generate an entitlement for free healthcare. Secondly, the rights and the responsibilities of the local governments were curtailed in all areas from education to garbage collection, which meant in practice that virtually all the hospitals and polyclinics then managed locally were earmarked for state takeover. This is exactly what happened in the next few years. According to legislation passed in November 2011, 43 hospitals and outpatient care institutions owned by the local county governments, as well as the healthcare institutions operated by the Budapest municipal government, would become the property of the state on 1st January $2012 .{ }^{6}$ By December 2012 the remaining 53 hospitals and dozens of outpatient specialist care institutions had been taken over by the state.

Both fundamental constitutional changes were implemented without any consultation with the State Secretariat for Healthcare within the Ministry of Human Capacities. From October 2010 to June 2011, the Secretariat worked on a 145-page comprehensive programme, entitled Resuscitated Health Care - Recovering Hungary [7], in which the ministry's experts committed themselves to keep the single-payer Social Insurance system intact and leave the hospitals in the hands of local governments. ${ }^{7}$ In the Secretariat's plans, the establishment of the institutional system of care management built on regional units played the crucial role. It was planned to create eight regional centres, each responsible for the care of 1-1.6 million inhabitants. Initially, this plan had been supported by the government, but it was later set aside, as the government's overall policy was aimed at achieving the maximum centralisation of all decisions - including the allocation of healthcare resources in the form of capital expenditure.

Once these discrepancies became obvious, the State Secretary, Dr. Miklós Szócska, meekly abandoned his own programme, but continued in office until the end of his 4-year mandate. ${ }^{8}$ Although it was not recognised by many people, Dr. Szócska was courageous and consistent in his public statements to describe the new constitutional set-up as a "National Health Service" as opposed to "Health insurance system" or "Social security", as it was called between 1992 and 2010. ${ }^{9}$ Actually, the constitutional changes meant that Hungary restored the pre1990 legal organisation of tax-funded healthcare finance. In a technical-administrative sense the state-run pension system and health funds are both going to be liquidated in the course of 2017 and their staff taken over by the Treasury, which is directly subordinated to the Ministry of Finance. With this decision - yet to be fully implemented - the U-turn will be completed. The 20-year work of earlier governments to reinstitute the pre-1945, Bismarckian multiplayer, German-type social insurance will have been crushed - probably for a generation [15].

\section{Healthcare is not a priority}

Before the elections of 2010, the medical profession and many industrial stakeholders, such as the pharmaceutical companies, medical device suppliers and patient groups, honestly believed that after the exceptionally strong and explicit pre-election promises, the health and healthcare would become a top priority for the new government. This would mean that the sector's share of the 
GDP would, at the expense of the public purse, increase considerably. After all, FIDESZ had opposed the Liberal reforms in the period $2006-2008^{10}$ in vocal and visible forms. The party had been the chief initiator of the 2008 plebiscite against the patient's healthcare fee of HUF 300 per doctor's visit, or for a day in hospital [18], a political position which greatly contributed to the fall of the then ruling Socialist-Liberal coalition government. FIDESZ published street posters promising to "resuscitate" the Hungarian healthcare system and secure substantial additional funding for the sector, hence the title of the former State Secretary's Programme.

However, the opposite occurred. After existing for 59 years, the Ministry of Health was abolished, meaning that there is no politician at the level of State Secretary present at government meetings with responsibility for healthcare. With the benefit of hindsight, it is clear that the government has been following the economic logic elaborated by Orbán's chief economic adviser and later the Minister of Economy, Mr. György Matolcsy. In a voluminous academic work written before he took office [19], Matolcsy's main message was that for the country as a whole, the Number 1 priority is to accelerate the growth of the GDP. Once this is achieved, improvements in the social spheres of education, health, housing etc. are going to be automatic. As he formulated in his book "there are at least 10 policy measures which are more important than the reform of healthcare". In the view of the present author, this line of reasoning does make good sense. Across country, comparisons show that there is, indeed a strong correlation between per capita GDP levels on the one hand and the performance of certain sectors of the economy, such as healthcare or education on the other. In the absence of output growth and convergence towards that of the more advanced countries, there is no possibility of improving the healthcare sector alone. Unfortunately, the very ambitious growth plans put forward by Mr. Matolcsy, an average annual GDP growth of 7\% for a period of 10-15 years, has never been achieved. Therefore, the national economy has not generated the anticipated additional revenue for the state, or for the households from which higher health expenditures could have been expected to be easily financed. In the period between 2011 and 2016, the average growth rate was a meagre 1.9 per cent. However, this is unrelated to the question of sectoral priorities.

Furthermore, the author is convinced that after controlling the country's level of economic development, the quality of services in the Hungarian healthcare sector is still noticeably better than that of many other sectors of the economy, such as education, rail transport, the military and environmental protection. In more concrete terms, this means that the average Hungarian patient is not treated significantly worse in a Hungarian hospital than he, or she, would be in an Austrian hospital, despite the almost $2: 1$ difference in the per capita GDP of the two countries. There is straightforward explanation for this. The effectiveness of medical services is determined primarily by medical knowledge, which spreads quickly across borders at no cost - consequently, there is not much difference in the skills of Hungarian and Austrian doctors. The second driver of high quality treatment is the patients' access to new medicines. In this respect, the Hungarian system is rather generous. By and large, the same pharmaceutical preparations are used in the two countries.

Thus, the above is sufficient to explain why the $2^{\text {nd }}$ Orbán government deliberately neglected the healthcare sector in the period 2010-2014. It was more concerned about cutting the fiscal deficit and promoting the growth of GDP and the indications of this prioritisation appeared very early. In the context of the mandatory framework of the EU harmonisation policy, by March 2011 the Orbán government had announced a new Economic Convergence Plan, which aimed at the reduction of public debt. The approved measures included significant spending cuts in education and reducing social benefits whilst spending more money on to incentivising private enterprises and consolidation of the indebted public enterprises. The financing of the healthcare sector was one of the first victims of spending cuts [20]. The total health costs, including all out-of-pocket payments, dropped from $8 \%$ of GDP in 2003 to $7.1 \%$ in 2014. Of this total, the proportion of public finance fell from $5.7 \%$ in 2003 to $4.8 \%$ in 2015. According to the OECD, the share of government and compulsory health insurance schemes as a percentage of current expenditure on health remained essentially unchanged at 68.3 per cent between 2009 and 2016. The public savings were mostly achieved in the pharmaceutical sector ${ }^{11}$, as outpatients are now obliged to pay on average $35 \%$ higher co-payments, than before, and to a lesser extent on diagnostics, as more and more patients are willing to pay private providers rather than waiting for a public sector cost-free appointment. In addition, in 2011 austerity measures were applied to the provision of sickness benefits. The maximum amount of sickness benefit was reduced by 50 percent and the so-called passive sickness benefit, claimed after the status of insuree was abolished. In order to avoid abuse of the system of sickness benefit, any doctor who wrongfully identifies an inability to work is obliged to share the cost of repaying the wrongly received cash benefits.

\section{The failed attempt to promote private health insurance}

As a result of a secret deal between Prime Minister Orbán and the CEOs of the foreign owned insurance companies, a minor amendment was made in the personal income tax law in 2011, by which all firms would be allowed to purchase tax free private health insurance for their employees as an optional non-wage benefit. Prior to this amendment, the personal income tax law provided tax exemption only for the cost of accident and permanent disability insurance. In January 2013 additional amendments were made to the income tax law, whereby risk insurance paid by another person becomes tax free if the monthly cost does not exceed $30 \%$ of the minimum wage. An employer's group health insurance can be obtained for about HUF 7,000 per month independent of the employees' age. An extra benefit package that includes 
VIP inpatient care starts from HUF 12,000 per month. The insured individuals benefit from such arrangements as they receive treatment more rapidly than in the public system. They do not simply move up the waiting list of patients covered by the national social insurance system, but are moved onto another, shorter list. This is only possible because the inadequate level of financial resources has resulted in public hospitals having spare capacity. Thus, such capacities may be used for the treatment of private patients. In this way the waiting lists for the costfree surgical interventions within in the state sector became somewhat shorter.

Initially, many public health care institutions enthusiastically supported these arrangements because they allowed them to obtain extra income. It was hoped that private health insurance might help hospitals' finances by providing them with additional funds. For a period, it appeared that the new tax-measures would bring a breakthrough and open the way for an American-type private health insurance market. However, this did not happen. The large insurance companies were reluctant to launch a major PR campaign, so the initial enthusiasm slowly dissipated. In mid-2017, there are very few fully-fledged private insurance policies on the market. It seems that the demand for such products is limited to a dozen large, multinational companies, which are willing to provide the VIP benefits to the top $1-5 \%$ of their employees.

\section{Unceasing administrative changes}

As stated earlier, the ownership and management tasks of the healthcare providers have been withdrawn from the local municipalities. This has all been entrusted to a newly established mega background-institution, the so-called National Institute for Organizational and Quality Development in Healthcare and Medicines (GYEMSZI). This was established in 2011 by merging several, previously separate institutes within the former Ministry of Health, namely:

- National Institute of Quality Development and Hospital Engineering (EMKI);

- National Institute of Pharmacy (OGYI);

- National Institute of Strategic Health Research (ESKI) and

- Institute of Health Care Professional Training and Continuing Education (ETI).

Apart from being the focal point of the nationalisation process, GYEMSZI was also intended to be responsible for the coordination of care, in line with the planned, but later abandoned, eight new regional divisions of health administration. The expectation was that state ownership of the inpatient care providers would facilitate the required restructuring of bed-capacity, and achieve cost saving through the centralised procurement of medicines, supplies and infrastructure services such as electricity, gas, and water. Some efficiency gains have been achieved, such as on the cost of utilities and a reduction in the pharmaceutical sub-budget of the Health Insurance Fund (HIF) by almost 25\% from 2011 to 2012 . However, only a small part of the latter can be attributed to savings on centrally procured hospital drugs. Overall, the estimated total cost saving for the initial years was not more than 10 billion HUF, which is less than $3 \%$ of the HIF's sub-budget for annual acute inpatient care. It is important to note that the bulk of GYEMSZI efforts were focused on the establishment of the centralised administration and management systems, which was, and still remains, an enormous task. More importantly, the expectations regarding the easier restructuring of the inpatient care sector have been only partially achieved. Paradoxically, the weakest achievements were obtained in Budapest, where the diverse hospital ownership structure had previously hampered coordinated investments and rationalisation. ${ }^{12}$

While the reform was, in many respects, still in the process of implementation, following the general election in 2014, the government decided to reorganize GYEMSZI. The tasks and responsibilities of GYEMSZI were streamlined to the ownership, supervision and management of state hospitals. From $1^{\text {st }}$ March 2015 the organization was renamed as the Centre of State Health Care Provision (ÁEEK). The tasks related to health information management and to care-coordination were transferred to the National Health Insurance Fund Administration (NHIFA), while the registration and licensing of pharmaceuticals is now carried out by the re-established National Institute of Pharmacy.

However, the changes were not finished. At the end of 2016, it was announced that NHIFA itself would cease to exist from the beginning of 2017 and most of its tasks related to health policy formation would be taken over by the Ministry of Human Capacities. Therefore, the change took place. The National Institute for Health Development was integrated into the Ministry of Human Capacities on 1 April 2017. Certain tasks and responsibilities of the institute were transferred to the National Healthcare Service Centre (ÁEEK) ${ }^{13}$, including the provision of special health services and the implementation of EU funded projects.

There is one area, where the centralisation process does have the potential to enhance efficiency and quality gains: the handling of medical records and financerelated statistical data. Perhaps these benefits are not too far away. The launch of a new electronic network for healthcare information (EESZT) by November 2017 is planned. The system will store patients' information electronically, making it easier for doctors working in different institutions to access the relevant data. Documents related to all treatment received over the last 5 years will be added to the system. In order to protect sensitive data, individuals will be able to grant or restrict access by others through their so-called "government gateway", an already well-functioning electronic system for matters related to official documentation. Because EESZT will be integrated into the existing systems, hospitals and pharmacies will not need to update their IT capabilities to use the new program. As part of this project, an attempt will be made to eliminate the paper-based administration of drug prescription by doctors and the purchase of drugs in the pharmacies.

The converse is that the endless administrative changes have undermined the formative spirit of hospital 
directors and the medical profession at large. From the mid-1980s, these people were accustomed to a considerable degree of managerial independence. Following the changes in 2010, they feel they are being betrayed and deceived. All decisions are made over their heads in Budapest. In reality, they cannot even keep up with the administrative changes, so they do not know whom to contact. When the $2^{\text {nd }}$ Orbán government assumed office in 2010, one of the first administrative measures that provoked open resistance among leading health professionals, was the ministerial decree announcing that applications submitted by candidates aged 62 or older for the position of a hospital director at state-owned healthcare providers would not be considered. In spite of protests from many organisations, this rule has remained in force. In contrast, the January 2016 plan of the State Secretary Dr. Ónodi-Szücs to nominate chancellors over each hospital director was torpedoed by the incumbent directors, consequently the plan has been shelved - at least for the time being.

The large hospitals accumulate deficits year after year, chiefly because the hospital directors do not attempt to balance their budgets. Most have debts that are more than 60 days overdue. However, the management knows from experience, that in the end all the hospitals will be bailed out. To date, in line with their expectations, this has happened every year since 2010 . This leads to a vicious circle. These budget overruns mean that the suppliers to state-owned healthcare institutions know that they will not be paid on time. Consequently, they price this delay into their sales contracts. As a result, the healthcare costs keep spiralling upwards in an otherwise non-inflationary macroeconomic environment.

\section{The conflicts arising from the disproportionate injection of capital and labour into the health sector}

After Hungary joined the European Union in 2004, support funds gradually became available for the country from the EU. By 2010, many large modernisation programmes were well underway, including in the healthcare sector. Of the 199 physically stand-alone hospitals throughout the country ${ }^{14}, 119$ received capital funding through this process. In the seven-year EU budget cycle between 2010 and 2016, more than 400 bn HUF ( $€ 1.3$ bn) were allocated to the hospitals in a framework comprised of 439 individually tendered projects. The bulk of this money was used in rural areas, because the EU rules excluded Budapest, as it was considered to be a higherthan-average EU region for this type of support.

Most of the money migrated to the very large hospitals: 20 inpatient facilities absorbed 61 per cent of the 400 bn HUF. In the provincial vs. Budapest comparison, the distribution showed significant differences: 41,000 HUF per inhabitant in the provinces and 7,000 HUF per inhabitant in Budapest. Given Budapest's large share of the country's population, the contrast is visible even for non-professionals: beautiful new facilities in middle-size towns and dilapidated hospital buildings in downtown Budapest. Naturally, the government is fully aware of the tensions. In the framework of the "Healthy Budapest Programme" the modernisation of two large hospitals on the Pest side has been promised and a third hospital with 2058 beds will be built as a greenfield investment on the Buda side to serve Budapest and its surrounding population of about 4.5 million people. The other 21 hospitals and 30 university clinics in the capital city can also count on fresh money from the programme's planned total budget of HUF $600 \mathrm{~m}$, but some will lose their independence and become "partner hospitals" of the three large centres.

This rainfall of "free" money for capital expenditure reached the recipients at a time when the public sector was experiencing unprecedented shortages of doctors, nurses, technicians and even administrative staff. Since there is no legal way to convert investment money into pay, enormous tensions have emerged. Many newly created facilities are unable to operate at the planned capacity levels because of persistent shortages of staff. A growing number of doctors and nurses, being very dissatisfied with their salaries and the extraordinary working load in the public hospitals, have gradually transferred their time from the public sector to the private sector. The consequence is that, on paper, the country has more filled physician positions, 42 thousand, than at any time in the past. However, a large part of this is fictitious. For example, a doctor having two specialist qualifications, for example as a rheumatologist and a traumatologist, working full-time in a given hospital in a specific department, is reported in the statistics as being two specialists filling two jobs in two different departments on a halftime basis. Under the existing regulations, the hospital is "forced" to cheat; otherwise, the regulatory authorities would withdraw the licence from one of the departments because of its inadequate level of staff.

The government has tried to improve the situation by regular pay increases. Gross salaries in the state-financed human health institutions and social services sector rose by 71 per cent between 2010 and 2016, more than twice the national average of $30 \%$. Unsurprisingly, these pay increases significantly impacted on the macro statistics: the share of GDP devoted to public health has bounced back in the last three years from $4.8 \%$ in 2014 to $5.2 \%$ in 2016 and will rise further in 2017 (Graph 1).

But this is not enough to mitigate the tensions in the sector's labour market, especially because acute labour shortages have afflicted the entire economy since 2015 in all sectors from street sweeping to nuclear medicine. The discontent of doctors is so entrenched, that in many state hospitals and outpatient centres the best specialists are employed only half, or quarter-time, and they spend the rest of their time working in the private sector. Thus, those who stay in the state sector - mostly newly qualified graduates - have to cope with ever worsening conditions. The shortage of qualified medical personnel has been further aggravated by the accelerated outward migration caused by Austria and Germany fully opening their labour markets in 2011. More and more clinicians are working in these two countries, or in the UK and Norway. As the borders are open and the labour contracts vary from 


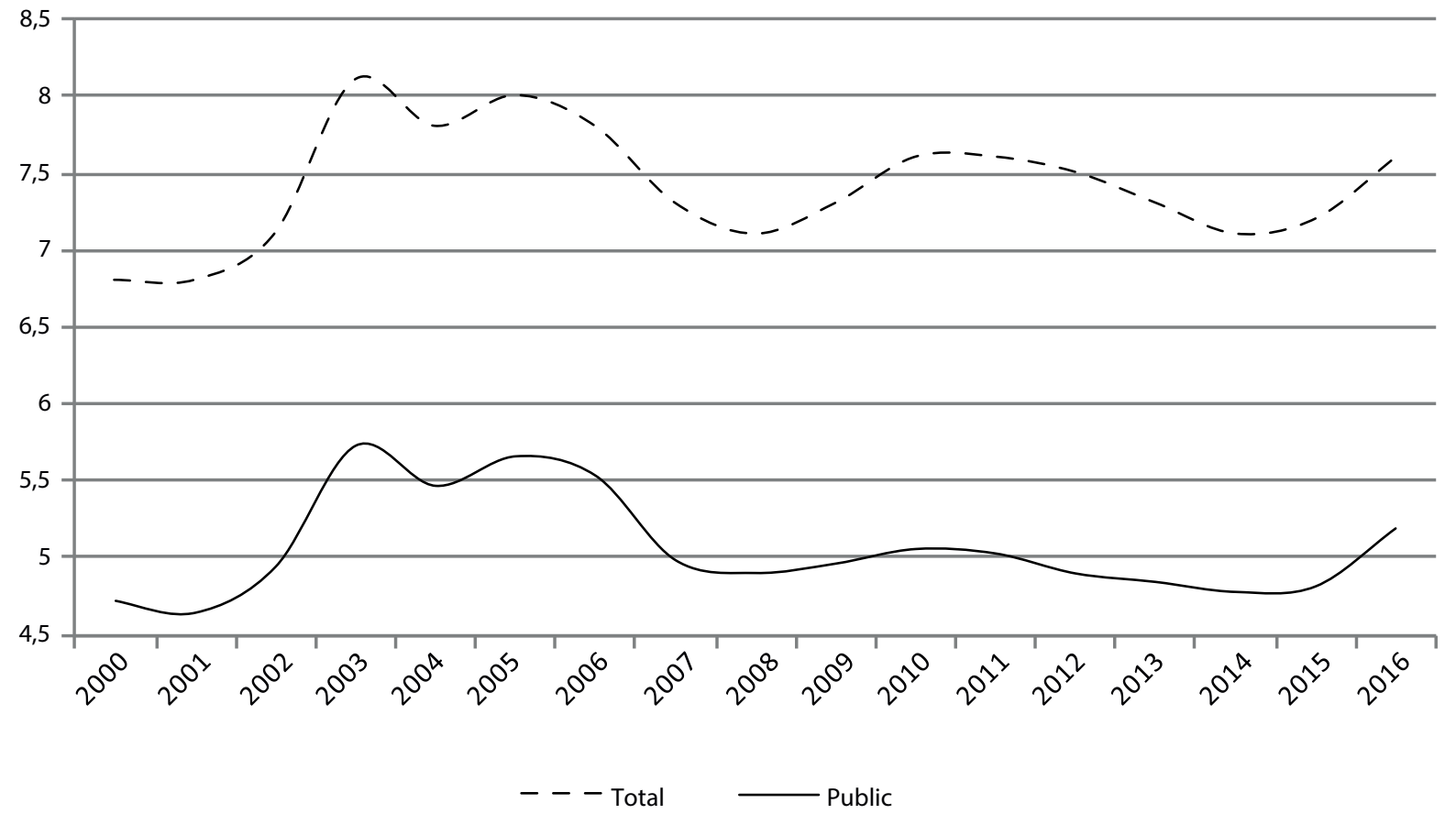

Graph 1. Current healthcare expenditures as a percentage of GDP, 2000-2016.

Source: OECD Health Statistics 2017 - Frequently Requested Data.

place to place, there are no good data on the magnitude of this brain drain. In-depth research revealed further problems. Staff attrition and feminisation of the profession are equally important as elderly doctors are often retired against their own will ${ }^{15}$, whilst young female professionals leave their jobs for reasons of maternity [21].

\section{Limiting competition in the retail pharmaceutical trade}

From July 2010 to January 2011, Parliament banned the establishment of new pharmacies in municipalities with an existing public pharmacy; moreover, giving a concession for the merging of pharmaceutical enterprises has also been prohibited. At the same time, the intention to change the rules for establishing and operating pharmacies was announced. There were two factors behind the announcement. Firstly, the national association of pharmacists had strong lobbying power and, secondly, the new government wanted to protect the interests of Hungarian pharmacies from competition by the German and Austrian pharmacy chains. This plan was implemented by a law that was passed in December 2010. ${ }^{16}$ In future, the establishment of a public pharmacy will be allowed only in municipalities where:

- a public pharmacy has not yet been put established, or

- the population served by the public pharmacy, together with the existing enterprise, is at least 4000, or in greater municipalities 4500 , or

- where the distance between the entrance to the existing public pharmacy and that of the new public pharmacy is 250 metres in towns with more than 50000 inhabitants and at least 300 metres in other municipalities.
New public pharmacies may be established only when the pharmacist has the majority ownership. In case of existing pharmacies, there is a legally stipulated transition period for obtaining majority ownership of the pharmacy by the pharmacists. ${ }^{17}$ Since $1^{\text {st }}$ January 2011, pharmaceutical companies or pharmaceutical wholesalers have not been allowed to acquire direct or indirect ownership of public pharmacies, and after $31^{\text {st }}$ May 2011, offshore companies were not permitted to own pharmacies. The law also restricts the activity of pharmacy chains. Not more than four pharmacies are allowed to come under the direction of an individual company or group of companies. Nevertheless, a few large, nationwide pharmacy chains did emerge after their lawyers found a legal loophole in the form of franchise agreements. ${ }^{18}$

\section{Taxation and prohibition measures to promote life-style changes}

In the past decade, for good reasons, several changes aimed at promoting a healthier life-style have emerged. Since the mid-1980s, there is a widespread belief inside and outside the country that Hungary's mortality rates are saliently high given the country's overall economic development, the accessibility to medical care and the almost free cross-border flow of clinical and pharmacological knowledge [22].

There is ample statistical evidence to prove that Hungarians have been pursuing a self-destructive life styles in several, important areas for decades. As shown in Mihalyi (2010) this is the delayed consequence of three rapid, but in many ways, controversial modernisation processes. 
1. As a result of forced industrialisation, urbanisation and the collectivisation of agriculture, the working and employment conditions had a negative impact on the health of workers during the socialist period. After the almost total abolition of small-scale private entrepreneurship, the autonomy and the chance of self-satisfaction by the state-employed workers and peasants - males in particular - were suppressed to a low and stress-generating level.

2. The relative openness of Hungary towards Western values since the 1960s has led to a growing stratification of society, implying - inter alia - significant differences in the longevity of the population which is dependent on the level of educational attainment, low, middle or high, and gender. Of the OECD countries, this type of inter-group inequality was by far the highest in Hungary. On average the gap in life expectancy at the age of 25 between the higher and lower-educated people is about 8 years for men and 5 years for women. However, in Hungary the corresponding figures are 13.9 years for men and 5.7 years for women. In other OECD countries, education and gender, taken together, do not explain more than $11 \%$ of the total variation in lifespan, but in Hungary they explain $30 \%$ of the variation. ${ }^{19}$

3. When large numbers of people were squeezed out of the labour market after the regime change in 1989, many of them tended to look for short-term consolation in the most self-destructive ways. Analysing the significant variables individually- like smoking, drinking, consumption of non-healthy food and a lack of physical exercise - Hungary is not the worst post-communist country, but it is the only one in which all these negative life-style factors present themselves excessively at the same time.

If the third conjecture is correct, it is very alarming. For many chronic diseases it is well-documented that the probability of death is much higher when more than one negative life-style factor is present at the same time. For example, the simultaneous effect of smoking and drinking to excess on mortality is much greater than the arithmetic summation of the negative impact of smoking or drinking evaluated separately.

All the above appears to be true when directly comparing Poland and Hungary, despite the fact that Hungary spends 15 per cent more than Poland on healthcare in absolute terms per capita, 1863 USD against 1622 USD. [23] More specifically, after adjusting for the population size, Hungary has more doctors, more nurses, more hospital beds and consequently Hungarians have many more consultations with doctors than Poles $-11.8 /$ head/year in Hungary against only $7.4 /$ head/year in Poland. The spending on research into health and medicine matters is also higher in Hungary. In spite of the higher spending, the outcomes for Hungary are inferior to those of Poland. According to the World Bank computerised database, the difference in maternal mortality per 100,000 live births is simply shocking, with 17 in Hungary but only 3 in Poland. Under-five and neonatal mortality rates display similar, although slightly smaller differences. This is likely to be related to the fact that the adolescent birth rate per 1000 women aged 15-19 of 19.8 in Hungary is also much higher than the Polish figure of 14.0. As far as the total population is concerned, the life expectancy at birth is almost two years higher in Poland at 77.7 years than Hungary's figure 75.9 years. There is little doubt that the main reason for the differences in life expectancy and mortality data is the result of the systematic differences in life-styles and external factors harmful to health. Once again, limiting our examples to a Polish-Hungarian comparison, the data show that the frequency of smoking, alcohol consumption and obesity are all greater in Hungary. The mortality rate attributed to household and ambient air pollution is almost twice as high at 122.8 per 100000 population in Hungary as opposed to 68.9 in Poland.

In view of the significance of these figures and the obvious desire to promote healthy life-styles, Parliament introduced a public health product tax or "chips tax" in 2011. The aim of the legislation was to reduce the consumption of unhealthy foods, by promoting a healthy diet, and provide additional finance for the health services, especially the public health programmes. The products affected included soft drinks, energy drinks, pre-packaged sweet goods, salty snacks and seasonings, if their sugar, salt or caffeine contents are above a certain level. The amount of tax levied is currently $250 \mathrm{HUF} /$ litre for energy drinks or $250 \mathrm{HUF} /$ kilogram for salty snacks. A new law on the protection of non-smokers came into force on $1^{\text {st }}$ January 2012. This legislation prohibited smoking in public places, restaurants, bars and workplaces. It is also illegal to smoke at bus stops; in underpasses used by pedestrians and in, or within $5 \mathrm{me}-$ tres, of playgrounds. Smoking is banned in schools, child welfare institutes and health service providers, including their grounds. In 2014, a new regulation came into effect to control the quantity of trans fats, unsaturated fats, in food. Since then, it has been illegal for foods to be sold if 100 grams of the total fat contains more than 2 grams of trans fats. The regulation applies to oils, fats and fat emulsions that are themselves produced for consumption or as components of a food product. Hungary became the third country in the European Union to regulate the quantity of trans fats in food products.

\section{Conclusions}

This paper's main assertion is that since 2010 the Hungarian healthcare system has been undergoing fundamental changes, despite it not being a priority for the present government. All major changes have happened as a collateral consequence of changes initiated in other parts of the economy. Today, the pre-1990 system of taxfinancing and centralised decision-making has been restored. After the liberal-minded, market oriented reforms in the early 1990s, and in the period 2006-2008, Viktor Orbán reversed these developments and reintroduced the system to something very similar to the Semashko model of centrally planned economies. Today, all major decisions are made by central government; the relative independence of the healthcare sector has been substan- 
tially curtailed. In terms of the relative level of financial support, the sector receives slightly more resources than other government-supported activities. The share of statistically recorded and unrecorded out-of-pocket payments on health has been rising steadily. However, fixed capital investments in the sector have moved very sharply upwards, almost exclusively due to generous, non-debt creating EU finance. Compared to the availability of human resources, doctors, nurses and other staff, the capital invested in the sector is simply excessive - as the newly created and/or modernised facilities are underutilised.

Important legal and fiscal measures have been introduced to penalise unhealthy lifestyles - smoking, drinking, consuming unsaturated fats - but the positive effects of such measures will be seen only in the longer-term. In many other important areas, peoples' health is dependent on their education and income, where the positive benefits will come even more slowly. Since the Hungarian economy is not growing sufficiently rapidly, and therefore, its relative position vis-à-vis the core EU countries is not improving, the quality of health care is unlikely to improve significantly in the foreseeable future. As more and more medical staff are seeking a better future outside the country or outside of the state-financed healthcare institutions, the shortcomings of the healthcare facilities used by the poorer segment of the population are likely to grow at an alarming rate.

\section{Notes}

${ }^{1}$ Currently, the party's full name is: Fidesz - Hungarian Civic Alliance. Technically, the election was won by the alliance of the Fidesz-Hungarian Civic Union and the Christian Democratic People's Party (KDNP). In reality, however, KDNP is not a real party, it exists only on paper. In contractual terms, a few further political groupings representing the country's Roma population, certain agricultural producers, etc. are also included in the ruling coalition.

2 Approximately $50 \%$ of the Hungarian population live in settlements with less than 10,000 inhabitants.

${ }^{3}$ In Hungary, parliamentary and local government elections are always held in the same calendar year, in the spring and then in the autumn.

${ }^{4}$ For independent assessment of these changes see [3-6].

5 The base of the employers' tax is the gross income paid to the employee. The rate has been reduced by 5 percentage points from January 2017, thus currently the applicable social tax rate is $22 \%$. In 2017 , the rates for the employee part of the contributions are as follows: $10 \%$ pension contribution (uncapped) and $8.5 \%$ healthcare and unemployment contribution $(7 \%+1.5 \%)$, also uncapped.

${ }^{6}$ Act CLIV of 2011 on the financial consolidation of county self-management authorities, the take-over of county-owned institutions and the take-over of certain healthcare institutions owned by the City of Budapest.

${ }^{7}$ For a detailed description of the pre-2010 system, see [8-13].

8 Secretary of State Szócska (2010-2014) was followed in this office by Dr. Gábor Zombor (2014-2015), whose resignation led to the appointment of Dr. Zoltán Ónodi-Szücs (2015-to date).
9 In a way, this development had been foreseen in [14].

${ }^{10}$ For an English language summary of these reforms see $[16,17]$.

${ }^{11}$ Between 2000 and 2016, the central budget's subsidy to pharmaceutical retail prices fell in real terms by more than 20 per cent.

${ }^{12}$ In the capital city of Hungary, there are 33 stand-alone legal entities qualifying for the appellation "hospital". These 33 hospitals provide medical services for Budapest at 76 locations.

13 There is not much systematic reporting on the Hungarian developments in the English language. One useful source is the Hungarian Health System Scan, produced and distributed by the National Healthcare Service Centre (ÁEEK) since 2007.

${ }^{14}$ Due to the intensive centralisation, the number of administratively independent hospitals was reduced to 102 by 2016 . Physically, however, many hospitals operate in 4-10 different locations, many kilometres apart.

15 In 2010, government decrees forbid all public employees to work and draw old-age pension at the same time. In view of the sudden exodus of many experienced physicians and nurses, the government made an exception in the healthcare sector. Based on a case-by-case decision of the sector ministry, doctors and nurses beyond the legal retirement age are allowed to continue their work and receive a pay-supplement, which almost compensates them for the lost (or suspended) pensions.

${ }^{16}$ Act CLXXIII. of 2010 on the modification of certain health related acts.

17 The $50 \%$ limit was attained by 1 January 2017 with the exception of half a dozen of pharmacies, the licences of which were automatically withdrawn.

${ }_{18}$ The largest chain, controlled by a German family-owned company (PHOENIX Pharmahandel GmbH), has 139 contracting partners and a total of 167 retail outlets.

${ }^{19}$ OECD life span estimations in 23 member-countries for the year 2011 [23].

${ }^{20} 2016$ OECD data at current prices and constant purchasing power parities (PPPS).

\section{References}

1. Kornai J., Hungary's U-Turn, "Capitalism and Society" 2015; 10: 2.

2. Csink L., Schandam B., Varga Zs. A. (eds.), The Basic Law of Hungary - A first commentary, National Institute of Public Administration, Budapest 2012, http://www.nki.gov.hu/ nemzetkoezi-kapcsolatok/511-qthe-basic-law-of-hungarya-first-commentaryq-cim-koetet-bemutatoja- (accessed: 05.08.2017).

3. Fukuyama F., What's Wrong with Hungary, "The American Interest" 2012, 6 February, http://www.the-american-interest.com/2012/02/06/whats-wrong-with-hungary/ (accessed: 05.08.2017).

4. Müller J.W., Moscow's Trojan Horse. In Europe's Ideological War, Hungary Picks Putinism, "Foreign Affairs" 2014, 6 August, http://www.foreignaffairs.com/articles/141825/ jan-werner-mueller/moscows-trojan-horse (accessed: 5.08.2017).

5. Bugarič B., Protecting Democracy and the Rule of Law in the European Union: The Hungarian Challenge, LSE 'Europe in Question' Discussion Paper Series 2014; 79, July. 
6. Brodsky C., Hungary's Dangerous Constitution, "Columbia Journal of Transnational Law" 2015, http://jtl.columbia.edu/ hungarys-dangerous-constitution/ (accessed: 21.04.2016).

7. The Semmelweis Plan, Resuscitated Health Care - Recovering Hungary. (A professional concept), Bp.: Ministry of National Resources - State Secretariat for Health 2011; 27 June, http://www.gyemszi.hu/conf/upload/BEK610_001. pdf (accessed: 05.08.2017).

8. Orosz É., Burns A., The Healthcare System in Hungary, OECD Economics Department Working Papers, No. 241, OECD Publishing, Paris 2000, http://dx.doi. org/10.1787/088362842087 (accessed: 05.08.2017).

9. Gaál P., Health Care Systems in Transition: Hungary, WHO Regional Office for Europe on behalf of the European Observatory on Health Systems and Policies, WHO Regional Office for Europe, Copenhagen 2004.

10. Boncz I., Nagy J., Sebestény A., Körösi L., Financing of Health Care Services in Hungary, "European Journal of Health Economics" 2004; 5: 252-258.

11. Mihalyi P., Comparative study into causes of excess premature mortality in Hungary in comparison with selected CEE countries, Study prepared for the WHO Regional Office in Hungary, Budapest, Europe Ltd. 2010.

12. Mihalyi P., Continuities and Discontinuities in PostCommunist Healthcare Systems: The Case of Hungary, in: Himanshu Sekhar Rout (ed.), Health Care Systems: A Global Survey, New Century Publications, New Delhi 2010, Chapter 10: 197-217.

13. OECD, OECD Economic Surveys - Hungary, OECD, Paris 2012, March.

14. Kutzin J., Bismarck vs. Beveridge: is there increasing convergence between health financing systems?, 1st annual meeting of SBO network on health expenditure, 21-22 November 2011, Paris, OECD, http://www.oecd.org/dataoecd/19/4/49095378.pdf (accessed: 01.10.2017).
15. Marrée J., Groenewegen P.P., Back to Bismarck: Eastern European Healthcare Systems in Transition, Avebury Ashgate Publishing House, Aldershot 1996.

16. Mihalyi P. (ed.), Health Insurance Reform in Hungary, Vol. 1 (Dilemmas and Plans), Bp.: EUROPE Ltd. 2007.

17. Mihalyi P. (ed.). Health Insurance Reform in Hungary, Vol. 2 (Rise and Fall), Bp.: EUROPE Ltd. 2008.

18. Baji P., Pavlova M., Gulácsi L., Groot W., User fees for public health care services in Hungary: Expectations, experience, and acceptability from the perspectives of different stakeholders, "Health Policy" 2011; 102 (2): 255-262.

19. Matolcsy G., Éllovasból sereghajtó [From Vanguard to Bringing Up the Rear], Éghajlat könyvkiadó, Budapest 2008.

20. Mihalyi P., Spending cuts and centralisation in Hungarian healthcare as a response to the international financial crisis, "International Journal of Healthcare Management" 2012; 5 (3): 173-186.

21. Varga J., Out-migration and attrition of physicians and dentists before and after EU accession (2003 and 2011). The case of Hungary, Institute of Economics, Centre for Economic and Regional Studies, Hungarian Academy of Sciences. Budapest Working Papers on the Labour Market 2016, BWP - 2016/4.

22. Eris M., Improving Health Outcomes and System in Hungary, OECD Economics Department Working Papers 2012, No. 961, OECD Publishing, http://dx.doi org/10.1787/5k98rwqj3zmp-en (accessed: 05.08.2017).

23. Murtin F., Mackenbach J., Jasilionis D., Mira d'Ercole M., Inequalities in longevity by education in OECD countries. Insights from new OECD estimates, OECD Statistical Working Papers 2017/02, OECD Publishing, Paris 2017. 